\title{
IMPLEMENTASI BOYER-MOORE PADA APLIKASI PENCARIAN RUMUS MATEMATIKA DAN FISIKA
}

\author{
Halim Agung, Yogyawan \\ Program Studi Teknik Informatika \\ Universitas Bunda Mulia \\ J1. Lodan Raya No.2 Jakarta \\ hagung@bundamulia.ac.id, joshuayogyawan@gmail.com
}

\begin{abstract}
Abstrak
Sulitnya mencari dan menghafalkan rumus matematika dan fisika menjadi kendala bagi sebagian pelajar SMA terutama dalam menjawab soal yang ada. Dibutuhkan ketelitian untuk menentukan apa saja yang tercantum dalam soal tersebut. Penelitian ini meneliti bagaimana cara melakukan pendeteksian kata kunci yang terdapat pada soal matematika dan fisika sekaligus dicocokkan dengan menggunakan metode pencocokan kata. Algoritma yang digunakan untuk melakukan pencocokan kata adalah algoritma Boyer-Moore. Setiap data kata kunci yang ada di basis data akan diambil berdasarkan fisika atau matematika, kemudian dipecah per kata. Setelah data kata kunci sudah dipecah menjadi per kata, tiap kata kunci akan melakukan pencocokkan ke soal yang dimasukkan pengguna dengan metode pencocokkan kata. Setelah dicocokkan dan hasil pencocokkan berhasil, aplikasi akan menampilkan daftar rumus yang memiliki kata kunci cocok dengan yang ada di soal. Pengujian metode pencocokan kata dengan algoritma Boyer-Moore pada soal matematika dan fisika yang sebanyak 30 kali membuktikan bawah aplikasi dapat menampilkan daftar rumus yang sesuai dalam melakukan pencocokkan pola kata kunci di soal baik matematika maupun fisika tingkat SMA.
\end{abstract}

Kata kunci :

Pencocokan Kata Kunci, Boyer-Moore, Rumus, Matematika, Fisika

\section{Abstract}

Difficult to find and memorize math and physics becomes an obstacle for the majority of high school students, especially in answering the questions that exist. It takes precision to determine what is stated in the question. This study investigated how to make the detection of keywords contained in the math and physics as well matched using string matching method. The algorithm used to perform string matching algorithm is the Boyer-Moore. Each keyword data in the database will be taken based on the physics or mathematics, then broken down per word. Once the data has been broken down into key words per word, every keyword will perform matching to the matter that the user entered with a string matching method. Once matched and the matching result is successful, the application will display a list of formulas that have keywords match the one in question. Testing method of string matching algorithms Boyer-Moore in math and physics as much as 30 times to prove under the application can display a list of the appropriate formula in performing the pattern matching keywords in a matter of both mathematics and physics high school level.

Keywords :

String Matching, Boyer-Moore, Formula, Math, Physics.

\section{Pendahuluan}

Zaman Era Globalisasi ini teknologi semakin berkembang pesat begitupun bidang pendidikan dari zaman ke zaman. Banyak sumbangan dari ahli-ahli pendidikan di masa lalu. Terutama rumus-rumus yang mereka ciptakan dari tiap masalah yang belum terpecahkan saat itu. Mereka memecahkan masalah tersebut dan membuat rumus ciptaan mereka. Tiap bidang walau berbeda-beda namun memiliki hubungan yang mendasar. Sebagai contoh matematika, bidang tersebut sudah lama dan kuno namun berkembang dan terjadi disekitar aktifitas kita. Matematika adalah bidang yang selalu dikaitkan dengan berhitung, bahkan bidang tersebut memiliki 
segudang rumus yang saling berkaitan. Rumus-rumus dalam tiap bidang memiliki keunikan dan fungsional yang berbeda-beda tergantung masalah yang ada. Murid kadang susah untuk menghafal rumus-rumus yang rumit dan banyak. Mereka sering harus melihat buku pelajaran mereka lagi untuk mencari rumus yang bisa digunakan untuk masalah yang ada.

Rumusan masalah yang akan dibahas pada penelitian ini adalah Bagaimana penelitian ini dapat membantu para siswa SMA untuk mengatasi kesulitan dalam menjawab soal-soal Matematika dan Fisika dan dalam mencari dan menghafal rumus matematika dan fisika. Oleh karena itu, penelitian ini menerapkan algoritma Boyer-Moore pada aplikasi rumus matematika dan fisika tingkat SMA berbasis Android dengan pendeteksian kata kunci.

Tujuan penelitian ini untuk melakukan suatu penelitian terhadap algoritma Boyer-Moore dengan dibuatnya aplikasi pencarian rumus matematika dan fisika tingkat SMA berbasis Android yang dapat menampilkan list rumus yang berhubungan dengan setiap kata kunci dalam soal yang dimasukkan oleh user. Dengan adanya penelitian ini diharapkan dapat membantu para siswa SMA dalam meningkatkan hasil belajar mereka di sekolah.

\section{KAJIAN LITERATUR}

\section{II.1 Penelitian Terdahulu}

Berdasarkan hasil telaah terhadap penelitian yang berkaitan dengan algoritma Boyer-Moore, terdapat beberapa hasil penelitian yang dapat dijadikan dasar acuan kajian ini, antara lain:

1. (, A. D. (2006). Konsep Kecerdasan Buatan., Hansun, 2014), dalam papernya yang berjudul "Implementasi Algoritma Boyer-Moore pada Aplikasi Kamus Kedokteran Berbasis Android" yang menerapkan Algoritma Boyer Moore pada aplikasi kamus kedokteran menyatakan bahwa dengan algoritma Boyer-Moore berhasil dilakukan dengan persentase sebesar $100 \%$ dari responden menyatakan bahwa proses pencarian istilah pada aplikasi Kamus Kedokteran dapat memberikan penjelasan atau hasil yang sesuai dengan yang diharapkan.

2. (Rahmanita, 2014), dalam papernya yang berjudul "Pencarian String Menggunakan Algoritma Boyer Moore Pada Dokumen" yang menerapkan Algoritma Boyer Moore pada dokumen menyatakan bahwa Algoritma Boyer
Moore mempunyai keunggulan dalam waktu menemukan pattern yang akan dicari dalam ukuran file yang lebih besar dan efektifitas Algoritma Boyer Moore tergantung pada panjang kata yang dicari.

3. (Utomo, Harjo, Handoko, 2008), dalam papernya yang berjudul "Perbandingan Algoritma String Matching Brute Force, Knuth Morris Pratt, Boyer Moore dan Karp Rabin Pada Teks Alkitab Bahasa Indonesia" yang melakukan perbandingan pada algoritma String Searching Brute Force, Knuth-Morris-Pratt, Boyer Moore, dan Karp Rabin menyatakan bahwa pada algoritma Boyer Moore membuktikan semakin panjang polanya maka waktu pencarian juga semakin singkat dan untuk proses pencarian pola dalam teks pada Alkitab (lebih dari 26 alphabet) algoritma Boyer Moore yang paling cepat dibandingkan dengan Karp Rabin, Knuth-Morris-Pratt, dan Brute Force.

4. (Ramadhansyah, 2013), dalam papernya yang berjudul "Perancangan Aplikasi Kamus Bahasa Gayo Dengan Menggunakan Metode Boyer Moore" yang melakukan teknik pencarian kosakata dengan menggunakan kamus yang dilakukan oleh masarakat Gayo adalah dengan mencari urutan abjad dari suatu kata yang dicari, sehingga proses translasi yang dilakukan memakan waktu yang lama dan dengan menggunakan metode Boyer Moore maka proses pencarian translasi kata pada database dapat berjalan lebih cepat dan akurat.

5. \{Hakim, Juliana, 2016), dalam papernya yang berjudul "Implementasi Algoritma Boyer Moore Pada Web E-Katalog Flora dan Fauna Pulau Jawa dan Sumatera" yang menyatakan bahwa penerapan algoritma Boyer Moore memberikan kemudahan dalam pencarian informasi secara efisien mengenai flora dan fauna Indonesia yaitu khusus Jawa dan Sumatera.

\section{II.2 Metode Pencarian}

Pencarian atau pelacakan merupakan salah satu teknik untuk menyelesaikan permasalahan AI (Artificial Intelligence). Keberhasilan suatu sistem salah satunya ditentukan oleh kesuksesan dalam pencarian atau pencocokan (Arhami, 2006).
Halim Agung, Yogyawan

Jurnal Ilmiah Teknologi Informasi Terapan

Volume III, No I, 15 Desember 2016 


\section{II.3 Algoritma Boyer Moore}

Algoritma Boyer Moore dianggap sebagai algoritma pencocokan string yang paling efisien digunakan dalam berbagai aplikasi sehari-hari. Algoritma tersebut dikembangkan oleh Bob Boyer dan J. Stroher Moore pada tahun 1977.

Pada proses pencarian string algoritma BoyerMoore membaca karakter-karakter dari pola (pattern) dari kanan ke kiri. Dalam kasus dimana jumlah karakter pada pattern lebih sedikit daripada jumlah karakter pada teks maka algoritma tersebut menggunakan 2 buah fungsi precomputed. Dua buah fungsi pengubah ini disebut good-suffix shift. Aturan pada good-suffix shift bertujuan untuk menangani kasus dimana terdapat pengulangan karakter pada pattern. (Aulia, 2008).

Algoritma Boyer-Moore mempunyai empat konsep dasar di dalam proses pencarian string, yaitu :

\section{Preprocessing}

2. Right-to-left scan

\section{Bad-character Rule}

\section{Good-suffix Rule}

Precomputation dari algoritma Boyer-Moore terdiri dari bad-character preprocessing dan goodsuffix preprocessing. Prinsip dasar yang pertama dari algoritma Boyer-Moore adalah melakukan perbandingan antara pattern yang dicari dengan teks. Perbandingan pattern dengan teks dilakukan dari arah kanan ke kiri.

Perbandingan dimulai dengan membandingkan antara karakter paling kanan dari pattern dengan teks. Jika terjadi kecocokkan, maka perbandingan akan dilanjutkan dengan karakter yang disebelah kiri dari yang dibandingkan sampai ke karakter pertama dari pattern. Jika terjadi ketidakcocokkan maka akan dilakukan pergeseran yang ditentukan oleh 2 fungsi pergeseran yaitu bad-character shift dan good-suffix shift. Aturan dari bad-character shift dibutuhkan untuk menghindari pengulangan perbandingan yang gagal dari suatu karakter dalam teks dengan pattern. Aturan dari good-suffix shift dibutuhkan untuk menangani kasus yang di dalamnya terdapat pengulangan karakter pada pattern.

Secara sistematis, langkah-langkah yang dilakukan algoritma Boyer-Moore pada saat mencocokkan string adalah (Chiquita, Christabella, 2012) :

1. Buat tabel pergeseran string yang dicari (S) dengan pendekatan Match Heuristic (MH) dan Occurence Heuristic $(\mathrm{OH})$, untuk menentukan jumlah pergeseran yang akan dilakukan jika mendapat karakter tidak cocok pada proses pencocokkan dengan string (T).

2. Jika dalam proses perbandingan terjadi ketidakcocokkan antara pasangan karakter pada $\mathrm{S}$ dan karakter pada $\mathrm{T}$, pergeseran dilakukan dengan memilih salah satu nilai pergeseran dari dua tabel analisa string yang memiliki nilai pergeseran paling besar.

3. Dua kemungkinan penyelesaian dalam melakukan pergeseran S, jika sebelumnya belum ada karakter yang cocok adalah dengan melihat nilai pergeseran hanya pada tabel Occurence Heuristic, jika karakter yang tidak cocok tiak ada pada $\mathrm{S}$, maka pergeseran adalah sebanyak jumlah karakter pada $S$, dan jika karakter yang tidak cocok ada pada $S$, maka banyaknya pergeseran bergantung pada nilai tabel.

4. Jika karakter pada teks yang sedang dibandingkan cocok dengan karakterpada $\mathrm{S}$, maka posisi karakter pada $\mathrm{S}$ dan $\mathrm{T}$ diturunkan sebanyak 1 posisi, kemudian dilanjutkan dengan pencocokkan pada posisi tersebut dan seterusnya. Jika kemudian terjadi ketidakcocokkan karakter S dan T, maka dipilih nilai pergeseran terbesar dari dua tabel analis pattern, yaitu nilai dari tabel Match Heuristic dan tabel Occurence Heuristic dikurangi dengan jumlah karakter yang telah cocok.

5. Jika semua karakter telah cocok, artinya $\mathrm{S}$ telah ditemukan di dalam T, selanjutnya geser pattern sebanyak 1 karakter.

6. Lanjutkan sampai akhir string $\mathrm{T}$.

Kelebihan dari algoritma Boyer-Moore (Utomo, 2008) ini semakin panjang pola yang dicari maka waktu pencarian semakin singkat.

Sedangkan kekurangan algoritma Boyer-Moore adalah lebih lambat untuk pattern yang pendek dan tidak bagus untuk pencarian binary string. (Aulia, 2008). 


\section{III.Metodologi Penelitian}

Dalam pembuatan aplikasi terdapat beberapa kebutuhan fungsional dan non-fungsional dari hasil analisis yang dilakukan.

Untuk kebutuhan fungsional yang dibutuhkan untuk aplikasi ini adalah sebagai berikut :

a. Aplikasi ini harus memiliki fitur-fitur yang tidak rumit, mudah dipelajari dan digunakan oleh pelajar SMA

b. Aplikasi ini harus dapat melakukan pencarian rumus tertentu dengan cepat dalam hal ini matematika dan fisika tingkat SMA

c. Aplikasi ini dapat diakses 24 jam secara online pada smartphone berbasis android

Sedangkan untuk kebutuhan non-fungsional melibatkan perangkat keras, perangkat lunak dan pengguna. Untuk spesifikasi kebutuhan perangkat keras adalah sebagai berikut :
a. Processor : ARMv6 800MHZ
b. RAM : $843 \mathrm{Mb}$
c. Memori (Internal Storage) : 3,69 Gb
d. Memori (External Storage) : 14,83 Gb

Sedangkan untuk kebutuhan software yang mendukung pembuatan aplikasi ini adalah Android Studio, Bluestacks, MySQL.

Peneliti menggunakan beberapa tahapan yang harus dilakukan untuk menggambarkan sistem sebelum membuat aplikasi yang menggunakan algoritma Boyer-Moore. Metode yang digunakan dalam penelitian ini adalah metode Waterfall (Bassil, 2012).

\section{III.1 Flowchart}

Perancangan flowchart bertujuan untuk menggambarkan aliran proses dalam sistem. Flowchart yang dibuat adalah Flowchart Pencarian Text yang ditampilkan pada gambar 3 .

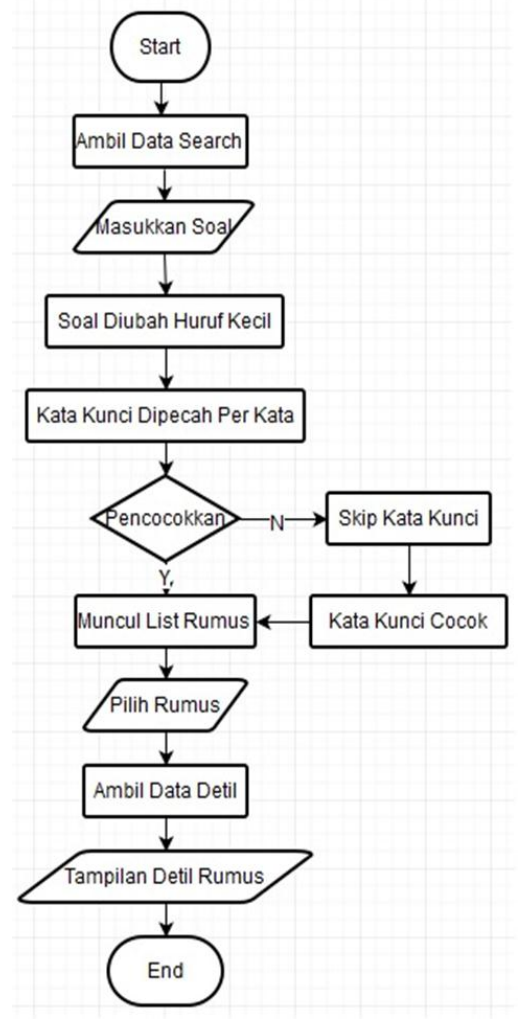

Gambar 3. Flowchart Pencarian Text

Flowchart diagram yang terlihat pada Gambar 3 adalah flowchart untuk menu search baik matematika ataupun fisika sekaligus menjelaskan saat aplikasi dijalankan hingga muncul detil rumus. Penjelasan secara detailnya adalah sebagai berikut :

a. User menjalankan aplikasi. Kegiatan ini diwakili oleh simbol terminator yang bertuliskan "START" yang berarti user mengakses menu search.

b. Saat user mengakses menu search, sistem akan mengambil data dari tabel detil berupa id rumus, nama rumus, kata kunci, bab, dan pelajaran. Kegiatan tersebut bertuliskan "Ambil Data Detil”.

c. Saat proses mengambil data sudah selesai, kemudian user akan memasukkan soal. Kegiatan tersebut bertuliskan "Masukkan Soal".

d. Setelah user memasukkan soal dan menekan button search, maka sistem akan langsung mengeksekusi dengan mengubah huruf-huruf soal yang dimasukkan user dengan huruf kecil 
(lowercase). Kegiatan tersebut bertuliskan "Soal Diubah Kata Kecil”.

e. Langsung setelah soal diubah menjadi huruf kecil, sistem juga mengubah data kata kunci menjadi per kata yang nantinya digunakan untuk dicocokkan ke soal. Kegiatan tersebut bertuliskan "Kata Kunci Dipecah Per Kata".

f. Setelah itu barulah sistem akan mencocokkan (kegiatan tersebut bertuliskan "Pencocokkan") kata kunci yang sudah menjadi per kata ke dalam soal yang sudah diubah menjadi huruf kecil. Bila ada kecocokkan maka akan muncul di list rumus (kegiatan tersebut bertuliskan "Muncul List Rumus"). Bila tidak ("Skip Kata Kunci"), sistem akan mencari lagi kata kunci yang hingga cocok ("Kata Kunci Cocok").

g. Setelah semua proses pencocokkan sudah selesai, hasil pencocokkan berupa list rumus yang data kuncinya cocok dengan apa yang ada di soal. User hanya tinggal memilih rumus apa yang ingin dilihat. Kegiatan tersebut bertuliskan "Pilih Rumus".

h. Setelah user memilih salah satu rumus di list rumus ("Pilih Rumus"), sistem akan langsung menampilkan halaman detil rumus. Halaman detil ini masih harus mengambil data dari database berupa tabel detil ("Ambil Data Detil").

i. Terakhir ialah tampilan halaman detil beserta detil rumus hasil pilihan user. Kegiatan tersebut bertuliskan "Tampilan Detil Rumus".

j. Setelah sudah di halaman detil dan tampil detil rumus, maka jalan sistem sudah selesai. Kegiatan tersebut bertuliskan "END".

\section{III.2 Use Case Diagram}

Dalam aplikasi pencarian matematika dan fisika tingkat SMA ini, user dapat melihat panduan untuk mengetahui tata cara memakai aplikasi ini, user bisa mengakses menu search, atau user bisa mengakses menu rumus secara manual. Menu search adalah proses dimana user memasukkan soal, kemudian hasil dari search akan berupa list rumus. Dan user bisa melihat halaman detil hasil dari aktifitas menu search dan menu rumus. Sementara aktor admin bertugas untuk memanipulasi data dengan memasukkan data rumus, mengubah, ataupun menghapusnya. Secara umum, fungsionalitas aplikasi ini dapat digambarkan pada diagram usecase seperti pada gambar 4.

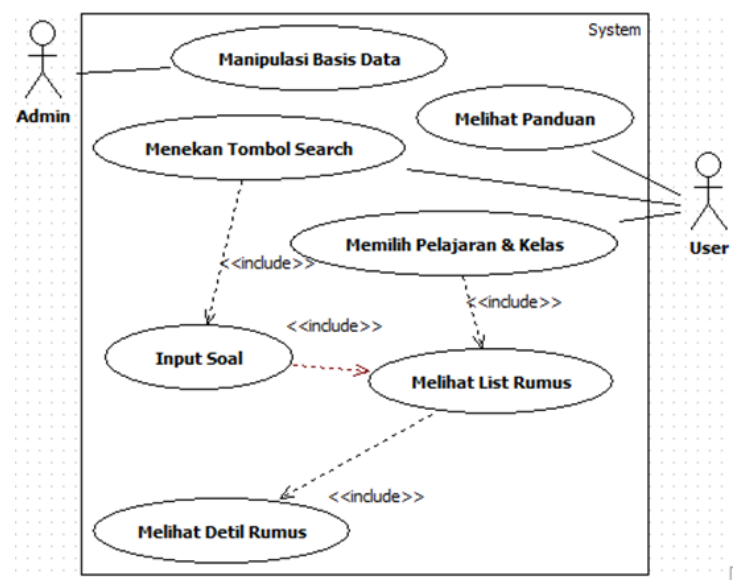

Gambar 4. Use Case Diagram Aplikasi

\section{III.3 Class Diagram}

Desain aplikasi ini dibuat berdasarkan class diagram seperti pada gambar 5, dengan penjelasan sebagai berikut:

1. Kelas lobby memiliki hubungan dengan kelas panduan, menu rumus, search matematika, dan search fisika. Karena kelas lobby adalah menu utama dari aplikasi ini. Memiliki 4 tombol gambar untuk akses ke panduan, 2 search, serta menu rumus.

2. Kelas panduan hanyalah kelas biasa berisikan teks panduan bagi user.

3. Kelas menu rumus adalah menu cari rumus secara manual, memiliki hubungan dengan kelas list. Kelas menu rumus memiliki 6 tombol gambar dengan masing-masing matematika dan fisika tingkat SMA.

4. Kelas menu list memiliki hubungan dengan JSONParser, Detil, AlertDialogManager, ConnectionDetector, dan AmbilDataList. Karena menu list ini sudah harus memakai koneksi internet

5. JSONParser memiliki hubungan dengan semua kelas yang memiliki permintaan mengambil data dari database. Seperti AmbilData, List, Detil, Search Matematika, dan Search Fisika. JSONParser adalah kelas jembatan antara MySQL dengan Android. 


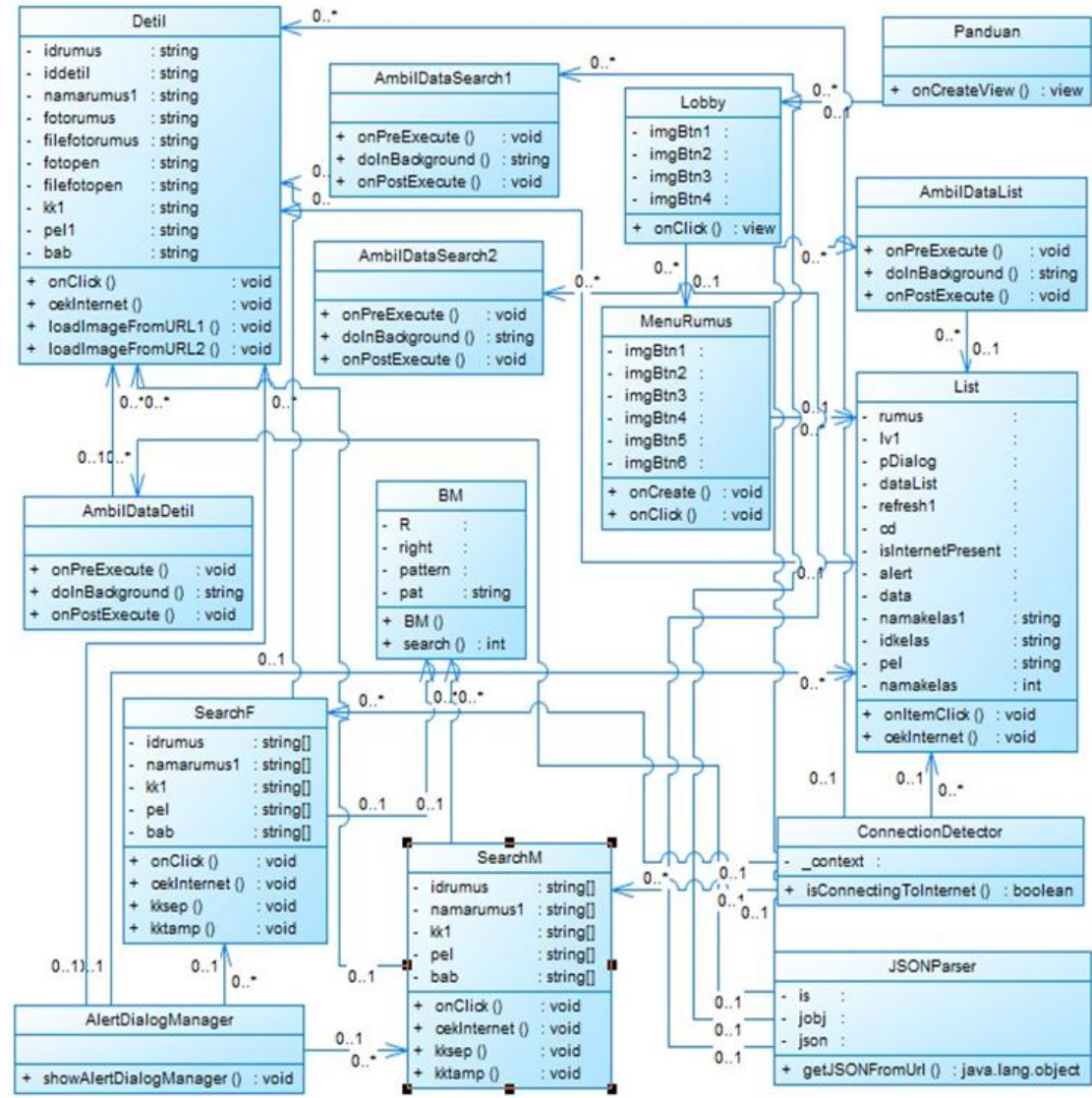

Gambar 5. Class Diagram Aplikasi

6. Kelas semacam AmbilData adalah kelas mengambil data dari database dengan 3 void. Karena database yang digunakan adalah MySQL dan Android tidak mengenal bahasanya, maka dibutuhkan kelas dengan nama JSONParser. onPreExecute() adalah proses mengirim URL ke database. doInBackground() adalah proses dibelakang layar dengan mengambil data hasil respon database lewat URL. onPostExecute() adalah proses menampung data ke dalam variabel tertentu.

7. Kelas SearchF dan SearchM adalah kelas search dengan tujuan yang sama namun beda pelajaran. Memiliki hubungan dengan AmbilDataSearch1, AmbilDataSearch2, BM, serta Detil.

8. BM adalah kelas algoritma Boyer-Moore yang berperan penting dalam aplikasi ini untuk bagian search rumus. BM memiliki hubungan dengan kelas SearchF dan SearchM.

9. Detil adalah kelas terakhir dan memiliki hubungan dengan SearchF, SearchM, dan List. Detil berperan penting dalam menampilkan detil rumus hasil dari ketiga kelas tersebut.

10. AlertDialogManager dan ConnectionDetector adalah kelas pendeteksi koneksi internet sekaligus validasi apakah terhubung atau tidak. Bila tidak maka sistem akan menampilkan notifikasi berupa tidak ada koneksi internet.

\section{III.4 Entity Relationship Diagram (ERD)}

ERD pada gambar 6 menampilkan implementasi basis data yang digunakan pada aplikasi ini. Aplikasi ini menggunakan 6 tabel dengan dua tabel (rumus dan detil) digunakan untuk menyimpan data utama pada aplikasi ini.

Halim Agung, Yogyawan 


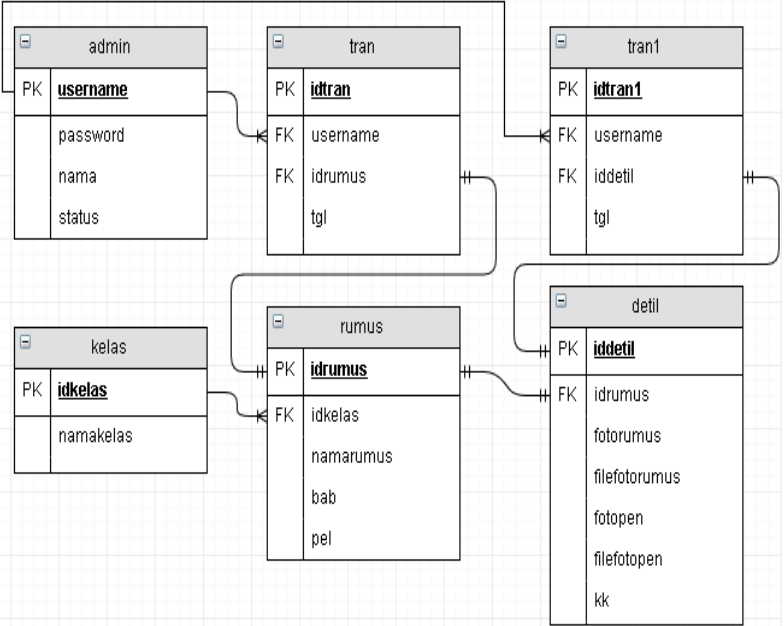

Gambar 6. ERD Aplikasi

\section{III.5 Arsitektur Sistem}

Diagram arsitektur sistem menjelaskan interaksi sistem dengan pengguna. Dalam kasus ini pengguna berinteraksi dengan Android. Android terhubung ke internet. Internet digunakan untuk mengakses server dimana server memiliki database dari sistem. Arsitektur nya ditunjukkan pada gambar 7 .

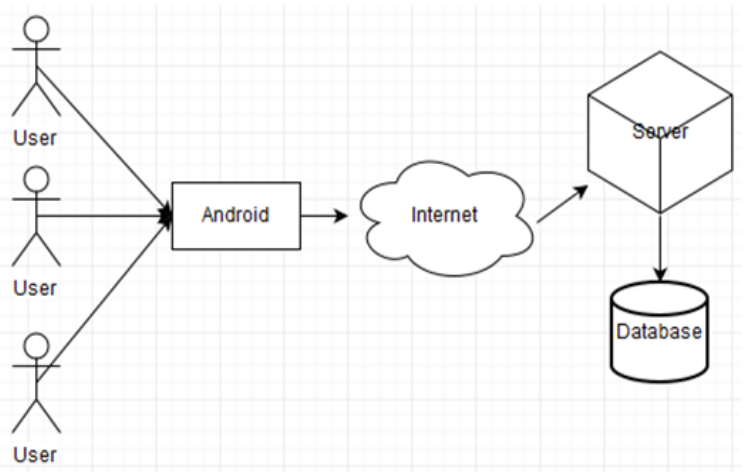

Gambar 7. Arsitektur Sistem

\section{III.6 Pseudocode Boyer-Moore}

Algoritma Boyer-Moore untuk mendeteksi apakah ada kata kunci yang terdapat pada soal yang dimasukkan user. Berikut pseudocode algoritma Boyer-Moore seperti terlihat pada gambar 1, gambar 2 dan gambar 3.

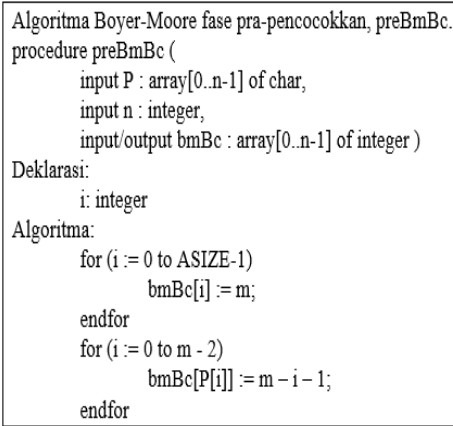

Gambar 8. Pseudocode Algoritma Boyer-Moore preBmBc

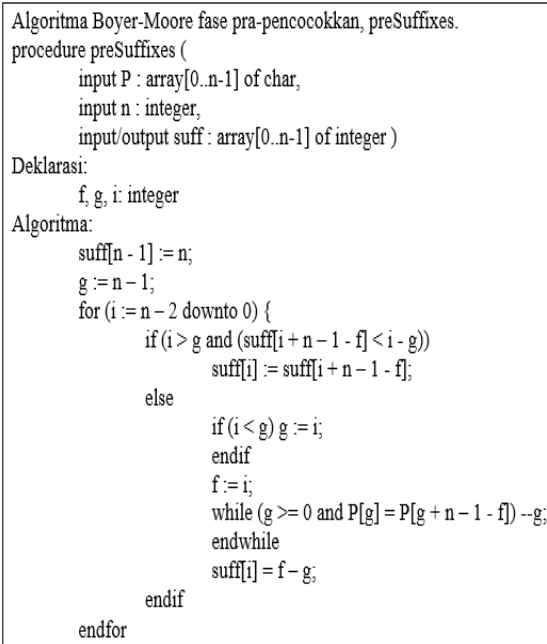

Gambar 9. Pseudocode Algoritma Boyer-Moore preSuffix

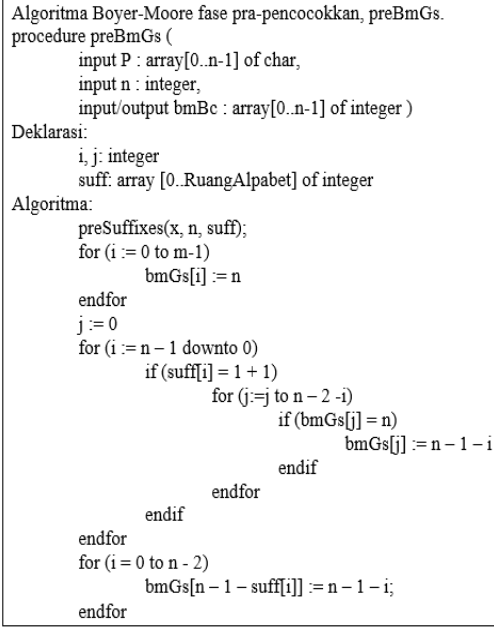

Gambar 10. Pseudocode Algoritma Boyer-Moore preBmGs

Halim Agung, Yogyawan 


\section{Hasil Penelitian dan Pembahasan}

Pada Aplikasi yang sudah mengimplementasikan algoritma Boyer-Moore, Pengguna dapat menjalankan aplikasi dan memilih menu search yang sesuai dengan keinginan user. Pengguna memasukkan soal seperti pada gambar 11:

\section{MPFormula}

Hitung kelajuan rata-rata, bila diketahui jarak yang ditempuh sebesar 5 meter dengan jangka waktu 3 detik

\section{SEARCH}

\section{Gambar 11. Tampilan Input Soal}

Kemudian setelah selesai memasukkan soal, user menekan tombol search. Kemudian sistem akan mengubah data kata kunci yang diambil dari database menjadi per kata melalui fungsi pada gambar 12.

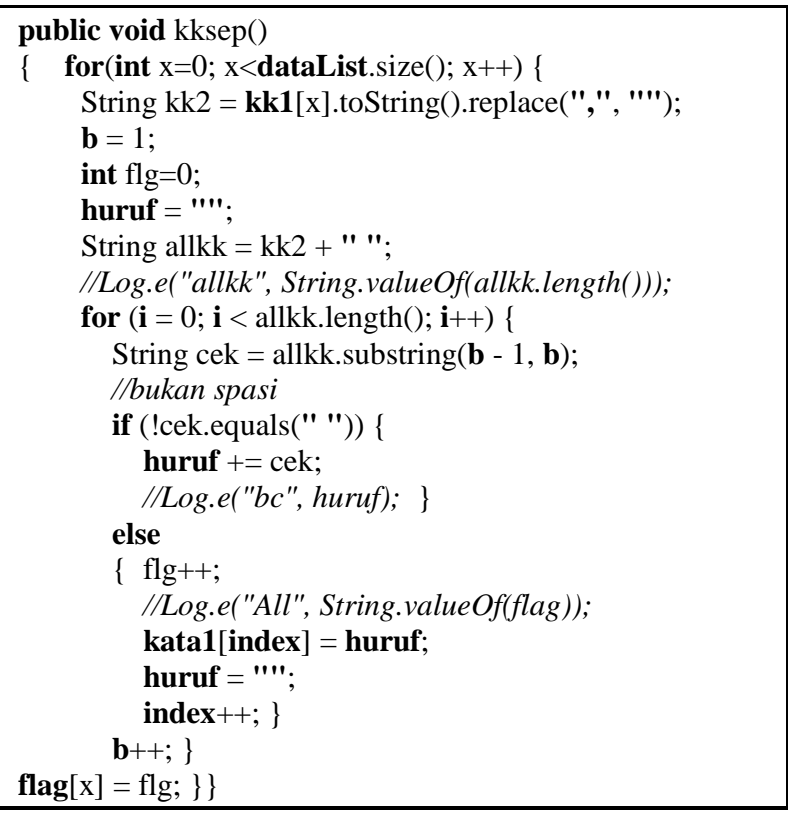

Gambar 12. Kode Program Pemisah Kata

Setelah kata kunci dipisah per kata melalui fungsi kksep(). Selanjutnya, sistem memasukkan setiap kata yang sudah dipisah per kata dimasukkan ke dalam variabel tamp. Selanjutnya masuk ke fungsi onClick() dimana kalimat yang dimasukkan pengguna diubah menjadi huruf kecil. Selanjutnya, sistem akan mengambil hasil tampungan kata kunci beserta dengan kalimat yang dimasukkan pengguna untuk dicocokkan menggunakan algoritma BoyerMoore. Kode Program dari Algoritma Boyer Moore dapat dilihat pada gambar 13 .

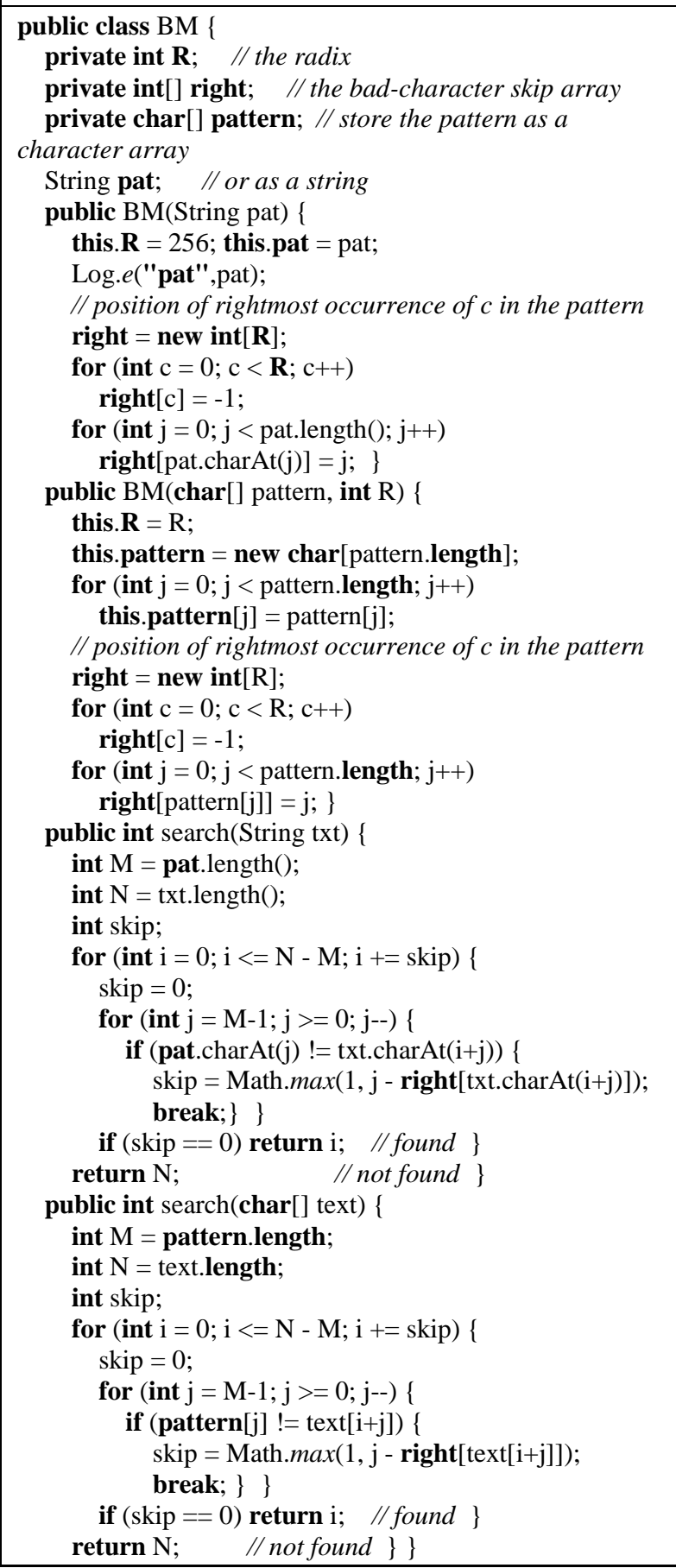

Gambar 13. Kode Program Algoritma Boyer-Moore 
MPFormula

Hitung kelajuan rata-rata, bila diketahui jarak yang ditempuh sebesar 5 meter dengan jangka waktu 3 detik!

$$
\text { SEARCH }
$$

Kelajuan Rata-Rata

jarak, kelajuan rata-rata, waktu

Gambar 14. Hasil Pencocokkan Menggunakan Algoritma Boyer-Moore
Kemudian untuk membuktikan algoritma BoyerMoore dapat berfungsi dengan baik pada aplikasi rumus matematika dan fisika maka dilakukan pengujian. Pengujian algoritma dilakukan dengan melakukan identifikasi kata kunci rumus pada input berupa soal atau beberapa kata untuk mendapatkan kata kunci yang sesuai dan apakah hasil rumus yang ditampilkan sudah sesuai dengan kata kunci. Tabel 1 menampilkan beberapa hasil pengujian dari 30 pengujian yang dilakukan pada penelitian ini.

Tabel 1. Tabel Pengujian Algoritma Boyer Moore

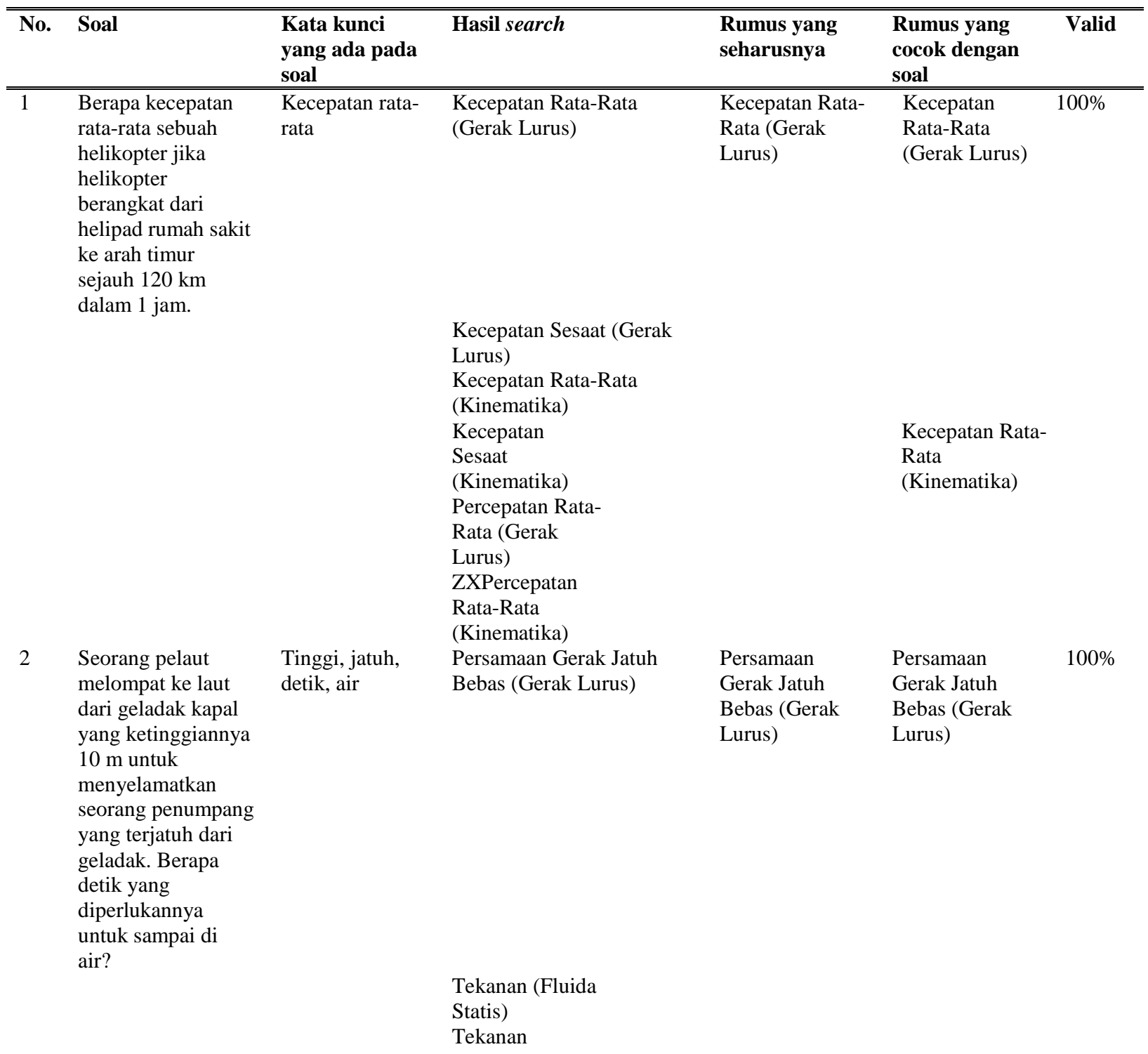

Halim Agung, Yogyawan 


\begin{tabular}{ll}
\hline \hline No. & Soal \\
\hline \hline & \\
& \\
& \\
& Sebuah kipas angin \\
& berputar dengan \\
& kecepatan 900 rpm \\
& (rotation per \\
& minute $=$ putaran \\
per menit). & Berapakah laju titik \\
di ujung baling- \\
baling, jika panjang \\
baling-baling 20 \\
cm?
\end{tabular}

4

Sebuah benda yang tingginya $10 \mathrm{~cm}$ diletakkan $60 \mathrm{~cm}$ di depan cermin cekung yang jarak fokusnya $15 \mathrm{~cm}$. Di manakah letak bayangan?

\section{Sebuah benda} bergetar harmonis dengan persamaan

$\mathrm{y}=10 \sin \pi_{\mathrm{t}}$ dengan y dalam $\mathrm{cm}$ dan t dalam sekon.

Tentukanlah amplitudo.
Kata kunci soal

\section{Berputar,} kecepatan, laju, putaran, laju, panjang

Rumus yang
seharusnya

Hidrostatis

(Fluida Statis)

Debit (Fluida

Dinamis)

Kecepatan Rata-Rata

(Gerak Lurus)
Kecepatan Pada Gerak Melingkar

Kecepatan

Pada Gerak

Melingkar
Valid cocok dengan soal

Kecepatan Sesaat (Gerak Lurus)

Kecepatan Linear (Gerak

Melingkar Beraturan)

Kecepatan Pada

Gerak

Melingkar

Percepatan

Sentripetal

(Gerak

Melingkar

Beraturan)

Tinggi, cermin, Perbesaran Linear (Optika cekung, jarak,

fokus, bayangan

Geometris)

Cermin

Lengkung

(Optika

Cermin

Lengkung

Geometris)

(Optika

Geometris)
Cermin

Lengkung

(Optika

Geometris)

Pembiasan

Cahaya (Optika

Geometris)

Bergetar, Persamaan Gerak

harmonis, Harmonik Sederhana

persamaan, sin,

sekon,

amplitudo
Persamaan

Gerak

Harmonik

Sederhana
Persamaan

Gerak

Harmonik

Sederhana

Frekuensi Pegas,

Periode Bandul

Usaha (Usaha \& Energi)

Teorema Usaha-

Halim Agung, Yogyawan

Jurnal Ilmiah Teknologi Informasi Terapan

Volume III, No I, 15 Desember 2016 


\begin{tabular}{ll}
\hline \hline No. & Soal \\
& \\
\hline \hline & dilakukan untuk \\
menggerakkan \\
sebuah mobil \\
bermassa $2.000 \mathrm{~kg}$ \\
dari keadaan diam \\
hingga mencapai \\
kelajuan $25,0 \mathrm{~m} / \mathrm{s} ?$
\end{tabular}

7

Sebuah bejana berbentuk silinder diisi fluida 200

$\mathrm{cm}^{3}$ dengan massa jenis

$\mathrm{kg} / \mathrm{m}^{3}$. Luas alas

bejana $20 \mathrm{~cm}^{2}$.

Hitunglah: a. tekanan pada dasar bejana, b. gaya yang bekerja pada dasar bejana.

Pada keadaan

normal $\left(\mathrm{t}=0^{\circ} \mathrm{C}, \mathrm{P}\right.$ $=1 \mathrm{~atm})$, berapakah volume 4 gram gas oksigen $\mathrm{O}_{2}$ ?

Nilai yang memenuhi persamaan: $2^{x+1}=$

\begin{tabular}{|c|c|c|c|c|}
\hline $\begin{array}{l}\text { Kata kunci } \\
\text { yang ada pada } \\
\text { soal }\end{array}$ & Hasil search & $\begin{array}{l}\text { Rumus yang } \\
\text { seharusnya }\end{array}$ & $\begin{array}{l}\text { Rumus yang } \\
\text { cocok dengan } \\
\text { soal }\end{array}$ & Palid \\
\hline $\begin{array}{l}\text { bermassa, kg, } \\
\text { kelajuan, m/s }\end{array}$ & & $\begin{array}{l}\text { Energi (Usaha \& } \\
\text { Energi) }\end{array}$ & $\begin{array}{l}\text { Usaha-Energi } \\
\text { (Usaha \& } \\
\text { Energi) }\end{array}$ & \\
\hline
\end{tabular}

Energi Kinetik (Usaha \&

Energi)

Teorema Usaha-Energi (Usaha

\& Energi)

Daya (Usaha \& Energi)

Energi Potensial (Usaha \&

Energi)

Fluida, massa

Tekanan (Fluida Statis)

Tekanan (Fluida

Tekanan

$100 \%$

jenis, $\mathrm{kg} / \mathrm{m}^{3}$,

Statis)

(Fluida Statis)

luas, tekanan,

gaya

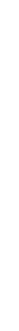

Tekanan Hidrostatis

(Fluida Statis)

Hukum Archimedes

(Fluida Statis)

Tegangan Permukaan

(Fluida Statis)

Kapilaritas (Fluida Statis)

Hukum Stokes (Fluida

Statis)

Atm, volume, Hukum Boyle-Gay Lussac gas

(Teori Kinetik Gas)

Persamaan Umum Gas Ideal

(Teori Kinetik Gas)

Tekanan Gas pada Ruang

Tertutup (Teori Kinetik Gas)

Kecepatan Efektif Gas Ideal

(Teori Kinetik Gas)

Persamaan Eksponensial

persamaan
Tekanan

Hidrostatis

(Fluida Statis)

Persamaan

Umum Gas

Ideal (Teori

Kinetik Gas)

Persamaan

Eksponensial
Tekanan Hidrostatis (Fluida Statis)

Persamaan

Umum Gas

Ideal (Teori

Kinetik Gas)
$100 \%$

Persamaan

Eksponensial

$100 \%$

Halim Agung, Yogyawan 


\begin{tabular}{|c|c|c|c|c|c|c|}
\hline No. & Soal & $\begin{array}{l}\text { Kata kunci } \\
\text { yang ada pada } \\
\text { soal }\end{array}$ & Hasil search & $\begin{array}{l}\text { Rumus yang } \\
\text { seharusnya }\end{array}$ & $\begin{array}{l}\text { Rumus yang } \\
\text { cocok dengan } \\
\text { soal }\end{array}$ & Valid \\
\hline 10 & $\begin{array}{l}\text { Himpunan } \\
\text { penyelesaian } \\
\text { pertidaksamaan } x^{2} \\
<9 \text { adalah... }\end{array}$ & pertidaksamaan & $\begin{array}{l}\text { Pertidaksamaan } \\
\text { Eksponensial } \\
\text { Persamaan Logaritma } \\
\text { Pertidaksamaan } \\
\text { Logaritma } \\
\text { Pertidaksamaan Kuadrat, } \\
\text { Ptk (Pertidaksamaan } \\
\text { Nonlinear) } \\
\\
\text { Pertidaksamaan Pecahan, PtP } \\
\text { (Pertidaksamaan Nonlinear) } \\
\text { Pertidaksamaan Irasional, PtI } \\
\text { (Pertidaksamaan Nonlinear) } \\
\text { Aturan Turunan } \\
\text { (Turunan Fungsi } \\
\text { Trigonometri) }\end{array}$ & $\begin{array}{l}\text { Pertidaksamaan } \\
\text { Kuadrat, Ptk } \\
\text { (Pertidaksamaan } \\
\text { Nonlinear) }\end{array}$ & $\begin{array}{l}\text { Pertidaksamaan } \\
\text { Kuadrat, Ptk } \\
\text { (Pertidaksamaan } \\
\text { Nonlinear) }\end{array}$ & $100 \%$ \\
\hline
\end{tabular}

\section{KESIMPUlan Dan SARAN}

Dari hasil penelitian diperoleh kesimpulan bahwa metode string matching dengan algoritma boyer moore dapat diterapkan pada aplikasi pencarian rumus matemtika dan fisika tingkat SMA yang disertai dengan pengujian algoritma sebanyak 30 kali dimana aplikasi dapat mencocokkan pola kata kunci pada soal serta menampilkan list atau kumpulan rumus matematika dan fisika tingkat SMA yang cocok dan sesuai dengan soal yang dikerjakan.

Untuk penelitian berikutnya yang dapat dikembangkan adalah dengan membuat penelitian yang membuat aplikasi yang dapat menjawab soal matematika dan fisika dengan disertai tahapan penyelesaian soal dan jawaban.

\section{REFERENSI}

Argakusumah, K.W., \& Hansun, S. (2014). Implementasi Algoritma Boyer-Moore pada Aplikasi Kamus Kedokteran Berbasis Android. Jurnal ULTIMATICS Vol.6. No.2.

Arhami, A. D. (2006). Konsep Kecerdasan Buatan. Yogyakarta: Andi.
Aulia, R. (2008). Analisis Algoritma Knuth Morris Pratt dan Algoritma Boyer Moore dalam Proses Pencarian String.

Bassil, Youssef, (2012), A Simulation Model for the Waterfall Software Development Life Cycle, International Journal of Engineering \& Technology (iJET), Vol.2. No.5.

Chiquita, Christabella. (2012). Penerapan Algoritma Boyer-Moore Dynamic Programming untuk Layanan Auto-Complete dan Auto Correct. Bandung.

Rahmanita, E. (2014). Pencarian String Menggunakan Algoritma Boyer Moore Pada Dokumen. Jurnal Ilmiah NERO Vol.1. No.1. hal 15-26.

Ramadhansyah. (2013). Perancangan Aplikasi Kamus Bahasa Gayo Dengan Menggunakan Metode Boyer Moore. Jurnal Pelita Informatika Budi Darma Vol.4. No.3. hal 118-122.

Utomo, D., Harjo, E.W., \& Handoko. (2008). Perbandingan Algoritma String Matching Brute Force, Knuth Morris Pratt, Boyer Moore dan Karp Rabin Pada Teks Alkitab Bahasa Indonesia. Jurnal Ilmiah Elektroteknika Vol.7. No.1. hal 1-13. 